\title{
Pathological Potential of Astroglia
}

\section{A. CHVÁTAL ${ }^{1,2}$, M. ANDĚROVÁ ${ }^{1,2}$, H. NEPRAŠOVÁ ${ }^{1,2}$, I. PRAJEROVÁ $^{1,2}$, J. BENEŠOVÁ ${ }^{1,2}$, O. BUTENKO ${ }^{1}$, A. VERKHRATSKY $^{1,3}$}

${ }^{1}$ Institute of Experimental Medicine, Academy of Sciences of the Czech Republic, Prague, ${ }^{2}$ Center for Cell Therapy and Tissue Repair, Charles University, Prague, Czech Republic, ${ }^{3}$ Faculty of Life Sciences, University of Manchester, Manchester, UK

Received February 15, 2008

Accepted April 16, 2008

On-line May 13, 2008

\section{Summary}

The pathological potential of glial cells was recognized already by Rudolf Virchow, Santiago Ramon y Cajal and Pio Del Rio-Ortega. Many functions and roles performed by astroglia in the healthy brain determine their involvement in brain diseases; as indeed any kind of brain insult does affect astrocytes, and their performance in pathological conditions, to a very large extent, determines the survival of the brain parenchyma, the degree of damage and neurological defect. Astrocytes being in general responsible for overall brain homeostasis are involved in virtually every form of brain pathology. Here we provide an overview of recent developments in identifying the role and mechanisms of the pathological potential of astroglia.

\section{Key words}

Astrocyte - Astrogliosis • Brain pathology • Brain damage and repair $\bullet$ Ischemia $\bullet$ Acute brain trauma $\bullet$ Neurodegeneration

\section{Corresponding author}

A. Chvátal, Institute of Experimental Medicine AS CR, Vídeňská 1083, 14220 Prague 4, Czech Republic. E-mail: chvatal@biomed.cas.cz

\section{Introduction}

Astroglial cells form a true backbone of the grey matter, by shaping the micro-architecture of the brain, creating independent neuronal-glial-vascular units (Fig. 1), providing neurons with energy and controlling extracellular ion- metabolite- and neurotransmitter homeostasis (Araque et al. 1999, Nedergaard et al. 2003,
Zonta et al. 2003, Haydon and Carmignoto 2006, Magistretti 2006, Oberheim et al. 2006, Verkhratsky 2006b,a, Verkhratsky and Toescu 2006, Giaume et al. 2007, Verkhratsky and Butt 2007). Further, astroglia actively participate in information transfer by accepting incoming information through a multitude of neurotransmitter receptors residing in astrocyte membranes (Verkhratsky et al. 1998, Verkhratsky and Steinhauser 2000, Volterra and Meldolesi 2005, Lalo et al. 2006, Verkhratsky and Kirchhoff 2007a,b) and feeding information back by virtue of regulated gliotransmitter release (Bezzi et al. 2004, Volterra and Meldolesi 2005). Information processing within astroglial networks, created by gap junctions connecting the terminal processes of astrocytes, operates in an intercellular volume transfer mode (Dermietzel 1998, Scemes and Giaume 2006) by direct exchange of second messengers, metabolites and other yet unidentified signalling molecules. This specific signaling mode brings much sophistication to information transfer and can potentially be relevant for higher brain functions (Allen and Barres 2005, Verkhratsky and Butt 2007). Finally, astrocytes control the genesis, survival and death of synapses (Ullian et al. 2004) and support adult neurogenesis through "stem" astrocytes subpopulations (Barres 1999, Berninger et al. 2006).

The pathological potential of glial cells was recognized already by Rudolf Wirchov (Tower 1992). Many functions and roles performed by astroglia in the healthy brain determine their involvement in brain diseases; as indeed any kind of brain insult does affect 
astrocytes, and their performance in pathological conditions, to a very large extent, determines the survival of the brain parenchyma, the degree of damage and neurological defect (Fig. 2). Furthermore, brain insults trigger a specific astroglial reaction, generally known as reactive astrogliosis. Astrogliosis is a defensive reaction, which is instrumental for limiting the areas of brain damage (by forming a scar) and for the aftermath of the lesions when reactive astroglia assists in the remodeling of the neural circuitry (Pěkný and Nilsson 2005).
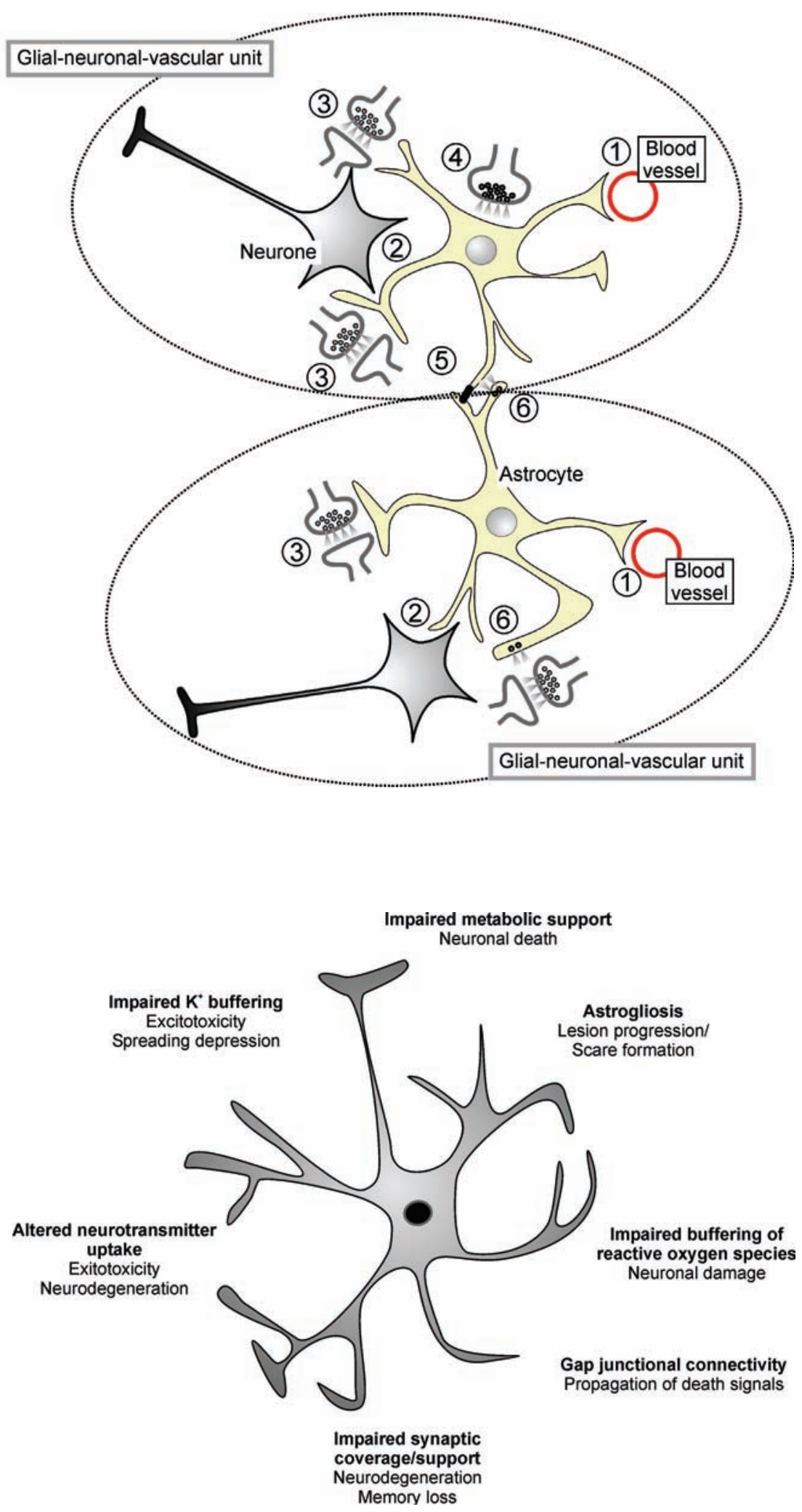

Fig. 1. Integrative role of astroglia. Grey matter astrocytes occupy clearly defined territories, where they form contacts with all neuronal membranes and send endfeet to neighboring capillaries thus creating relatively independent glial-neuronalvascular units. (1) The astroglial endfeet plaster the outer capillary wall and secrete yet unknown factors, which determine the appearance of tight junctions and hence the formation of the blood-brain barrier. By virtue of numerous transporters, astroglial cells provide for metabolite exchange between the brain parenchyma and blood vessels. Astroglial cells also release vasoconstricting/ vasodilating agents, which couple neuronal activity with local blood flow. (2) Astrocytes provide active neurons with energy substrates using the "astrocyteneuronal lactate shuttle". (3 - 4) Astrocytes receive signaling input from neurons using a host of receptors residing in astroglial membranes forming a "tripartite synapse" or in direct neuronal-glial synaptic contacts. (5) Astrocytes communicate between themselves by gap junctions or through the release of gliotransmitters. (6) Astrocytes communicate with neuronal circuits by gliotransmitters, which modulate synaptic transmission and affect neuronal excitability.

Fig. 2. Pathological potential of astrocytes. 


\section{Astroglia and ischemic insults}

As very often happens in nature, astroglia play a dual role in brain insults, providing for both defense and destruction of neural tissue (Nedergaard and Dirnagl 2005, Rossi et al. 2007). Indeed, incidences of reduced oxygen supply immediately trigger neuronal depolarization, with subsequent loss of ion homeostasis. Depolarization-induced $\mathrm{Ca}^{2+}$ influx results in massive release of glutamate, which induces further depolarization thus causing glutamate excitotoxicity, which assumes the central role in brain damage (Westbrook 1993). Overactivation of glutamate receptors results in massive cell overload with $\mathrm{Ca}^{2+}$, which in turn launches multiple forms of cell death (Nicotera et al. 2007).

Astrocytes represent the main part of the brain's defense against glutamate excitotoxicity, because they express high densities of glutamate transporters and accumulate up to $80 \%$ of total glutamate released in the brain (Danbolt 2001, Kirischuk et al. 2007). Moreover, astrocytes express huge amounts of the major ROS scavengers and anti-oxidants glutathione and ascorbate, which protect the brain against oxidative stress accompanying ischemia. Finally, by virtue of both local and spatial $\mathrm{K}^{+}$buffering astroglia remove excess $\mathrm{K}^{+}$from the extracellular space thus restraining neuronal depolarization (Giaume et al. 2007). Yet, in conditions of prolonged ischemia, glutamate cannot be contained within astroglia; depolarization and alteration of sodium gradients result in the reversal of glial glutamate transporters (Allen et al. 2004) and further massive release of glutamate; in addition, glutamate can be released from astroglia via exocytosis or through large membrane pores formed by, e.g., hemichannels or $\mathrm{P}_{2} \mathrm{X}_{7}$ receptors (Contreras et al. 2004).

The second important role played by astroglia in the progression of ischemic insults is associated with their intercellular connectivity, which is formed by gap junctions and unifies astrocytes into functionally continuous syncytium (Giaume et al. 1991, Bruzzone and Giaume 1999). Once more intercellular volume transmission through gap junctions plays a dual role in responses to ischemic injury as it may participate in either the removal of unwanted substances (e.g., $\mathrm{K}^{+}$buffering) or in spreading pathological signals. Both neuroprotective and detrimental roles of the astroglial syncytium received experimental support. Indeed, the neuroprotective role of the astroglial web is corroborated by the following observations: (i) inhibition of astroglial gap junctions by pharmacological agents enhanced neuronal vulnerability (ii) partial genetic deletion of $\mathrm{Cx} 43$, which forms a substantial part of glial gap junctions in vivo, increased sensitivity of neural tissue to stroke, which was manifested by a significant increase of stroke volume and (iii) specific deletions of $\mathrm{Cx} 43$ in astrocytes also increased neuronal vulnerability to ischemia (Giaume et al. 2007). At the same time a wealth of data supporting the pathological potential of gap junctional communications has been acquired recently. First, it was shown that astroglial gap junctions remain open during ischemia, and they can propagate certain death signals (Cotrina et al. 1998, Lin et al. 1998). Second, it appeared that inhibition of Cx43 expression by specific antisense oligodeoxynucleotides reduces neuronal death in response to glucose and oxygen deprivation, and pharmacological blockade of gap junctions decreases the stroke volume following occlusion of the medial cerebral artery (Nedergaard and Dirnagl 2005). Finally, gap junctions may participate in the generation of waves of spreading depression through the penumbra, which are critical for expansion of the infarct zone (Budd and Lipton 1998). It still remains unclear which conditions favor a neuroprotective or detrimental impact of the glial syncytium; they may depend on the severity of insult and brain region.

\section{Astroglia and acute brain trauma}

Mechanical brain injury or injections of toxic substances into the brain tissue (e.g. kainate lesions) trigger massive cell death and astrogliosis manifested by elevated expression of glial fibrillary acidic protein, GFAP (Bignami and Dahl 1977, Hozumi et al. 1990). The membrane properties of astrocytes in post-traumatic brain or spinal cord were investigated in vitro, in cultures of cortical (Perillan et al. 1999, Perillan et al. 2000) and spinal cord astrocytes (MacFarlane and Sontheimer 1997, 1998). These studies have demonstrated that reactive spinal cord astrocytes up-regulated several membrane conductances, including delayed outwardly rectifying $\mathrm{K}^{+}$ currents $\left(\mathrm{K}_{\mathrm{DR}}\right)$, transient A-type $\mathrm{K}^{+}$currents $\left(\mathrm{K}_{\mathrm{A}}\right)$ and voltage-gated $\mathrm{Na}^{+}$currents. Proliferating astrocytes demonstrated a down-regulation of inwardly rectifying currents $\left(\mathrm{K}_{\mathrm{IR}}\right)$, whereas in non-proliferating astrocytes $\mathrm{K}_{\mathrm{IR}}$ currents were increased.

Since many pathological states are accompanied by an increase in $\left[\mathrm{K}^{+}\right] \mathrm{e}$, an early event leading to the activation of astrocytes and the subsequent formation of a glial scar, several studies have examined the astrocyte 
membrane properties and cell volume regulation of astrocytes after exposure to high $\mathrm{K}^{+}$in situ (Anderova et al. 2001, Vargová et al. 2001, Anderova et al. 2004, Neprašová et al. 2007). Neprašová et al. (2007) found that spinal cord astrocytes, exposed to elevated $\mathrm{K}^{+}$, reacted by both morphological changes and the alteration of membrane properties and cell volume regulation.

The astrocytic response to a mechanical trauma, such as a cortical stab wound, is manifested by intense immunostaining for GFAP (Enclancher et al. 1990, Vijayan et al. 1990, Kálmán and Ajtai 2000, Nolte et al. 2001), S-100ß, a calcium-binding protein that is predominantly found in astrocytes, and for vimentin, a cytoskeletal protein expressed in reactive astrocytes (Perillan et al. 1999, Perillan et al. 2000). Nestin expression in reactive astrocytes has been also detected (Yagita et al. 2002, Anděrová et al. 2004). Astrogliosis also increases diffusion barriers in the CNS due to the hypertrophy of astrocytic processes and the increased production of extracellular matrix components (Syková 1997, Roitbak and Syková 1999, Syková and Chvátal 2000). This can impair the diffusion of ions, neurotransmitters, trophic factors and other neuroactive substances in the brain and thus influence the extent of CNS injury.

The voltage-dependent $\mathrm{K}^{+}$and $\mathrm{Na}^{+}$currents in reactive astrocytes have been extensively studied in situ
(Jabs et al. 1997, D'Ambrosio et al. 1999, Bordey et al. 2001). These studies have shown that reactive astrocytes express predominantly $\mathrm{K}_{\mathrm{DR}}$ while the expression of $\mathrm{K}_{\mathrm{IR}}$ is decreased, which may imply an impaired $\mathrm{K}^{+}$spatial buffering capacity and a failure of ionic homeostasis in gliotic CNS tissue, followed by abnormal neuronal activity. Expression of voltage-gated $\mathrm{K}^{+}$channels in astrocytes in vivo is affected by astrocyte proliferation at the site of injury; similar results were found in in vitro models of astrogliosis (MacFarlane and Sontheimer 1997, 1998). That is, proliferating astrocytes (identified by bromo-deoxyuridine staining) in the cortex of young rats (P16 - 24), which received a focal cortical freeze-lesion on the first postnatal day, demonstrated increased expression of $\mathrm{K}_{\mathrm{DR}}$ channels, but they did not appear to express $\mathrm{K}_{\mathrm{IR}}$ channels at all (Bordey et al. 2001). Investigations of Anderova et al. (2004) revealed the existence of two electrophysiologically, immunohisto-chemically and morphologically distinct types of hypertrophied astrocytes at the site of a stab wound, depending on the distance from the lesion (Fig. 3). "Proximal astrocytes", found within a distance of $\sim 100 \mu \mathrm{m}$ from the stab wound, showed an upregulation of $\mathrm{K}_{\mathrm{DR}}$ currents and were nestin and BrdUpositive, while nestin and BrdU-negative astrocytes, showing an up-regulation of $\mathrm{K}_{\mathrm{IR}}$ currents from 6 hours to 3 days after trauma, were localized more distantly from the site of wound $(>100 \mu \mathrm{m})$.

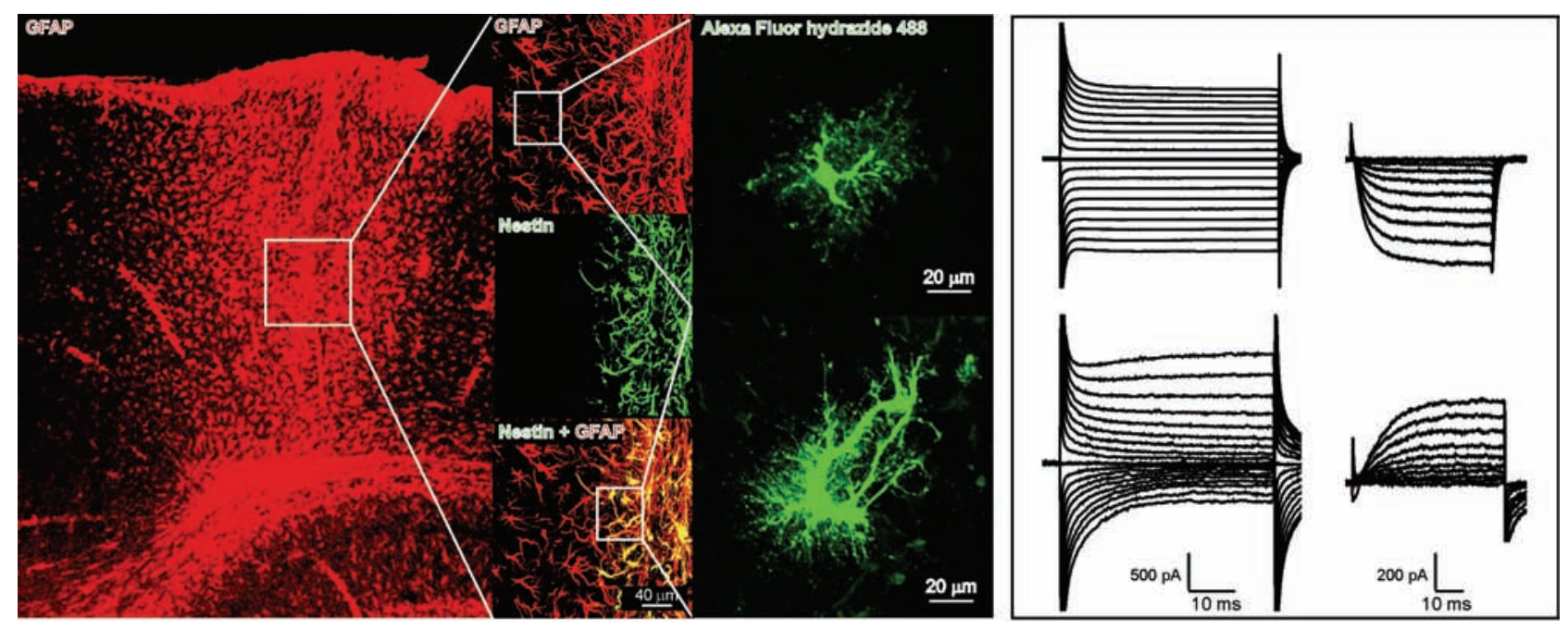

Fig. 3. Two immunohistochemically and electrophysiologically distinct types of reactive astrocytes were detected in the vicinity of a stab wound. Immunohistochemistry of a coronal section from the cortex of an injured rat 7 days post-injury-PI (lower magnification, left). Sections of the brain slices were stained for GFAP. Note the stronger expression of GFAP in the vicinity of the stab wound. Immunostaining for GFAP and nestin (higher magnification) and double immunostaining for nestin and GFAP (bottom, high magnification) in the cortex of a wounded rat 7 days PI. Note the presence of nestin-positive astrocytes (nestin+GFAP) only in the vicinity of the wound (double stained cells are yellow) and astrocytes positive only for GFAP. Typical membrane current patterns of astrocytes in the cortex of control rats and 7 days PI (right). Membrane current patterns in GFAP-positive and GFAP/nestin-positive were measured in response to voltage steps from a holding potential of $-70 \mathrm{mV}$. To activate the currents, the membrane was clamped for $50 \mathrm{~ms}$ from the holding potential of $-70 \mathrm{mV}$ to increasing de- and hyperpolarizing potentials ranging from -160 to $+20 \mathrm{mV}$, in $10 \mathrm{mV}$ increments. Note the large amplitude of inwardly rectifying $\mathrm{K}^{+}$currents in GFAP-positive astrocytes and large amplitude of outwardly rectifying $\mathrm{K}^{+}$currents in GFAP/nestin-positive astrocytes. 
Using several in vivo models of chemical CNS injury it was found that changes in the expression of various ion channels in post-traumatic astrocytes are directly affected by both the nature and the extent of the tissue injury. For instance, injection of kainate into the ventricles caused degeneration of hippocampal pyramidal cells in the CA3 region in concert with a significant reduction of functional $\mathrm{Ca}^{2+}$ channels in astrocytes in acutely isolated hippocampal slices (Burnard et al. 1990). Lesions induced by an intraperitoneal injection of kainate resulted in a loss of tetrodotoxin-sensitive $\mathrm{Na}^{+}$channels in reactive astrocytes in the adult rat hippocampus (Jabs et al. 1997). In the rat hippocampus, fluid percussion injury induced a decrease of $\mathrm{K}_{\mathrm{A}}$ and $\mathrm{K}_{\mathrm{IR}}$ currents (D'Ambrosio et al. 1999). Similarly, $\mathrm{K}_{\mathrm{IR}}$ currents were reduced in astrocytes from the dentate gyrus of adult rats subjected to an entorhinal cortex lesion (Schroder et al. 1999).

\section{Astroglia and chronic neurodegeneration}

Post-stroke dementia is a frequent outcome of ischemic insults; neurological defects that develop after stroke to a large extent are determined by the glia, because the degree of astrogliosis and its progression directly influence the size of the infarction and posttraumatic regeneration and remodelling.

Alzheimer's disease (AD), named after Alois Alzheimer who was the first to describe this pathology in 1907 together with post-stroke dementia, is the main cause of senile dementia. Progression of AD is associated with profound neuronal loss throughout the brain which rapidly affects memory and results in severe impairment of cognitive functions. Histological hallmarks of $\mathrm{AD}$ are (i) the formation of deposits of $\beta$-amyloid protein $(A \beta)$ in the walls of blood vessels; (ii) the accumulation of $A \beta$ plaques in the grey matter and (iii) the intra-neuronal accumulation of abnormal tau-protein filaments in the form of neuronal tangles (Dickson 1997, Selkoe 2001). $\mathrm{AD}$ is associated with prominent reactive astrogliosis and the activation of microglia (incidentally, the involvement of glial cells in the pathogenesis of $\mathrm{AD}$ was initially suggested by Alois Alzheimer himself in 1910). In fact, $\mathrm{AD}$ plaques are formed by $\mathrm{A} \beta$ deposits, degenerating neurites, astroglial processes and activated microglial cells (Wisniewski and Wegiel 1991).

Astrocytes appear as natural scavengers of $A \beta$, and in particular its toxic truncated form $\mathrm{A} \beta 42$ (Nagele et al. 2003). Astrocytes detect $A \beta$ deposits, cover them with their processes and take up and degrade the $A \beta$. This ability of astrocytes to take up $A \beta$ allowed Robert Nagele and his co-workers to propose a hypothesis about a leading role of astroglia in the progression of AD (Nagele et al. 2004). According to this hypothesis, at the very early stages the initial production of $A \beta 42$ in neurons trigger their initial degeneration and release of $A \beta 42$. The latter, together with products of neuronal destruction, activates neighboring astrocytes, which in turn start to accumulate $A \beta$ and clear the neuronal debris. Indeed, astroglial load by $A \beta 42$ directly correlates with the local density of plaques and the amount of extracellular $A \beta 42$ (Nagele et al. 2003). Incidentally, $A \beta 42$ accumulation coincides with significant increase in the concentration of neuronal nicotinic acetylcholine receptors in astrocytes, probably reflecting the very high affinity of the latter for A 342 (Nagele et al. 2004).

Overload of astrocytes with $A \beta 42$ compromises their function, thus affecting their support of other neurons within the astrocyte domain. Withdrawal of astrocytic support may initiate the degeneration of synapses and trigger the distant accumulation of $A \beta 42$. In addition, astroglia may even be instrumental in $\mathrm{A} \beta 42$ neurotoxicity: in vitro experiments have shown that treatment of astroglial-neuronal co-cultures with $A \beta$ results in the generation of $\left[\mathrm{Ca}^{2+}\right]_{\mathrm{i}}$ oscillations in astrocytes, without any apparent $\left[\mathrm{Ca}^{2+}\right]_{i}$ changes in neurons (Abramov et al. 2004a,b). These astroglial oscillations induced neuronal death in $\sim 24$ hours; inhibition of glial $\left[\mathrm{Ca}^{2+}\right]_{\mathrm{i}}$ responses was neuroprotective (Abramov et al. 2004a,b). Degeneration of the whole astrocyte domain results in lysis and the formation of an astroglial plaque. Subsequently, neighboring astrocytes become activated and send their processes towards the plaque, trying to clear the excess $A \beta$. The repetition of this process eventually recruits increasing numbers of astrocytes and through them astrocytic domains with their neurons, which in turn leads to dissemination of the plaques and neurological defects.

Amyotrophic lateral sclerosis. Amyotrophic lateral sclerosis (ALS), also known as 'Lou Gehrig's disease' (named after a baseball player who died from ALS in 1941) was initially described by Charcot in 1869. This disease is manifested by the degeneration of motor neurons located in the cortex, brain stem and spinal cord (Mitchell and Borasio 2007). This neurodegeneration results in progressive paralysis and muscle atrophy. The key pathological determinant of neuronal death in ALS is associated with deficient glutamate clearance, and as a 
consequence, excitotoxic neuronal damage. This deficient glutamate clearance results from the disappearance of the astroglial glutamate transporter EAAT2 in the affected brain areas (Barbeito et al. 2004) as a consequence of gene failure and may result from aberrant RNA splicing, exon skipping and intron retention. Experimental genetic deletion of EAAT2 (GLT-1) in mice faithfully mimicked ALS and led to the degeneration of motor neurons (Barbeito et al. 2004).

\section{Effects of elevated extracellular $\mathrm{K}^{+}$ concentration on astroglia}

Rapid increases in extracellular $\mathrm{K}^{+}$concentration $\left(\left[\mathrm{K}^{+}\right]_{\mathrm{e}}\right)$ in the CNS occur under many pathological states, such as ischemia, epileptical seizures, traumatic brain injury or spreading depression. In these pathological conditions $\left[\mathrm{K}^{+}\right]_{\mathrm{e}}$ can be elevated up to $80 \mathrm{mM}$, which significantly contributes to the damage of the nervous tissue (Somjen 1979, Syková 1983, Syková et al. 1992, Voříšek and Syková 1997, Somjen 2001). In addition, elevated $\left[\mathrm{K}^{+}\right]_{\mathrm{e}}$ may also trigger cell proliferation (Del Bigio et al. 1994) and can induce or modify apoptotic cell death $(\mathrm{Yu}$ 2003). Astroglia are responsible for extracellular $\mathrm{K}^{+}$homeostasis in the CNS; astrocytes remove excess $\left[\mathrm{K}^{+}\right]_{\mathrm{e}}$ through both $\mathrm{K}^{+}$uptake by $\mathrm{K}^{+}$ channels or transporters and through $\mathrm{K}^{+}$spatial buffering within the astroglial syncytium (Orkand et al. 1966, Somjen 2001, Kofuji and Newman 2004). Acute exposure of astrocytes to elevated $\left[\mathrm{K}^{+}\right]_{\mathrm{e}}$ results in reversible membrane depolarization, accumulation of intracellular $\mathrm{K}^{+}$and rapid cell swelling (Pasantes Morales and Schousboe 1988, Walz 1997).

Astrocyte swelling, which can be modelled in vitro by exposure to hypotonic solution or to an isotonic solution with an increased $\left[\mathrm{K}^{+}\right]$(Kimelberg et al. 1995, Chvátal et al. 1999, Anděrová et al. 2001, Vargová et al. 2001), evokes a large increase in extracellular $\mathrm{K}^{+}$in the vicinity of the cell membrane after a transient depolarization, the latter resulting from an extracellular space (ECS) volume decrease around swollen astrocytes. Syková et al. (1999) found that incubation of the spinal cord in $50 \mathrm{mM} \mathrm{K}^{+}$evokes cell swelling resulting in a decrease in the ECS volume fraction and astrocyte activation (manifested by an increase in GFAP immunoreactivity). This can lead to the impairment of both synaptic and extrasynaptic transmission, the diffusion of neuroactive substances and neuron-glia communication in the CNS (Syková 2005).

As has been discussed before, reactive astrocytes change the pattern of $\mathrm{K}^{+}$channels by down-regulating the expression of $\mathrm{K}_{\mathrm{IR}}$ and increasing the expression of $\mathrm{K}_{\mathrm{DR}}$. A decrease in $\mathrm{K}_{\mathrm{IR}}$ may directly impair $\mathrm{K}^{+}$buffering capacity and thus result in a failure of ionic homeostasis in gliotic CNS tissue, followed by abnormal neuronal activity. Our recent study (Neprašová et al. 2007) demonstrated that in complex astrocytes, pre-incubation with high $\mathrm{K}^{+}$caused depolarization, an increase in input resistance, a decrease in membrane capacitance and an increase in the densities of voltage-gated $\mathrm{K}^{+}$and $\mathrm{Na}^{+}$currents. Conversely, in passive astrocytes the reversal potential shifted to more positive values and the densities of $\mathrm{K}^{+}$and $\mathrm{Na}^{+}$currents decreased. No changes were observed in astrocyte precursors.

\section{Conclusions}

Astrocytes are involved in virtually every type of brain pathology. They play a dual role forming the brain defense system and at the same time exacerbating brain damage when severely insulted. Astroglial performance to a very large extent determines the outcome of brain pathology and the degree of neurological damage.

\section{Conflict of Interest}

There is no conflict of interest.

\section{Acknowledgements}

Research was supported by the Grant Agency of the Czech Republic (\#305/06/1316, \#305/06/1464, $\# 305 / 08 / 1384$ and 309/08/1381), by the Ministry of Education, Youth and Sports of the Czech Republic (\#1M0538 and \#LC554) and by the Academy of Sciences of the Czech Republic (\#AVOZ50390512). A.V. research was supported by The Alzheimer Research Trust (UK), The National Institute of Health (NIH), The Royal Society and The Wellcome Trust.

\section{References}

ABRAMOV AY, CANEVARI L, DUCHEN MR: Beta-amyloid peptides induce mitochondrial dysfunction and oxidative stress in astrocytes and death of neurons through activation of NADPH oxidase. $J$ Neurosci 24: 565$575,2004 a$. 
ABRAMOV AY, CANEVARI L, DUCHEN MR: Calcium signals induced by amyloid beta peptide and their consequences in neurons and astrocytes in culture. Biochim Biophys Acta 1742: 81-87, 2004b.

ALLEN NJ, BARRES BA: Signaling between glia and neurons: focus on synaptic plasticity. Curr Opin Neurobiol 15: $542-548,2005$.

ALLEN NJ, KARADOTTIR R, ATTWELL D: Reversal or reduction of glutamate and GABA transport in CNS pathology and therapy. Pflugers Arch 449: 132-142, 2004.

ALZHEIMER A: Über eine eigenartige Erkrankung der Hirnrinde. Allg Z Psychiat Psych-Gericht Med 64: 146-148, 1907.

ANDEROVA M, KUBÍNOVÁ S, MAZEL T, CHVÁTAL A, ELIASSON C, PĚKNÝ M, SYKOVÁ E: Effect of elevated $\mathrm{K}^{+}$, hypotonic stress, and cortical spreading depression on astrocyte swelling in GFAP-deficient mice. Glia 35: 189-203, 2001.

ANDEROVA M, ANTONOVA T, PETŘíK D, NEPRAŠOVÁ H, CHVÁTAL A, SYKOVÁ E: Voltage-dependent potassium currents in hypertrophied rat astrocytes after a cortical stab wound. Glia 48: 311-326, 2004.

ARAQUE A, PARPURA V, SANZGIRI RP, HAYDON PG: Tripartite synapses: glia, the unacknowledged partner. Trends Neurosci 22: 208-215, 1999.

BARBEITO LH, PEHAR M, CASSINA P, VARGAS MR, PELUFFO H, VIERA L, ESTEVEZ AG, BECKMAN JS: A role for astrocytes in motor neuron loss in amyotrophic lateral sclerosis. Brain Res Brain Res Rev 47: 263274, 2004.

BARRES BA: A new role for glia: generation of neurons! Cell 97: 667-670, 1999.

BERNINGER B, HACK MA, GOTZ M: Neural stem cells: on where they hide, in which disguise, and how we may lure them out. Handb Exp Pharmacol 174: 319-360, 2006.

BEZZI P, GUNDERSEN V, GALBETE JL, SEIFERT G, STEINHAUSER C, PILATI E, VOLTERRA A: Astrocytes contain a vesicular compartment that is competent for regulated exocytosis of glutamate. Nat Neurosci 7: 613620, 2004.

BIGNAMI A, DAHL D: Specificity of the glial fibrillary acidic protein for astroglia. J Histochem Cytochem 25: 466469, 1977.

BORDEY A, LYONS SA, HABLITZ JJ, SONTHEIMER H: Electrophysiological characteristics of reactive astrocytes in experimental cortical dysplasia. J Neurophysiol 85: 1719-1731, 2001.

BRUZZONE R, GIAUME C: Connexins and information transfer through glia. Adv Exp Med Biol 468: 321-337, 1999.

BUDD SL, LIPTON SA: Calcium tsunamis: do astrocytes transmit cell death messages via gap junctions during ischemia? Nat Neurosci 1: 431-432, 1998.

BURNARD DM, CRICHTON SA, MACVICAR BA: Electrophysiological properties of reactive glial cells in the kainate- lesioned hippocampal slice. Brain Res 510: 43-52, 1990.

CHVÁTAL A, ANDĚROVÁ M, ŽIAK D, SYKOVÁ E: Glial depolarization evokes a larger potassium accumulation around oligodendrocytes than around astrocytes in gray matter of rat spinal cord slices. J Neurosci Res 56: 493-505, 1999.

CONTRERAS JE, SANCHEZ HA, VELIZ LP, BUKAUSKAS FF, BENNETT MV, SAEZ JC: Role of connexin-based gap junction channels and hemichannels in ischemia-induced cell death in nervous tissue. Brain Res Brain Res Rev 47: 290-303, 2004.

COTRINA ML, KANG J, LIN JH, BUENO E, HANSEN TW, HE L, LIU Y, NEDERGAARD M: Astrocytic gap junctions remain open during ischemic conditions. $J$ Neurosci 18: 2520-2537, 1998.

D'AMBROSIO R, MARIS DO, GRADY MS, WINN HR, JANIGRO D: Impaired $\mathrm{K}^{+}$homeostasis and altered electrophysiological properties of post-traumatic hippocampal glia. $J$ Neurosci 19: 8152-8162, 1999.

DANBOLT NC: Glutamate uptake. Progr Neurobiol 65: 1-105, 2001.

DEL BIGIO MR, OMARA F, FEDOROFF S: Astrocyte proliferation in culture following exposure to potassium ion. Neuroreport 5: 639-641, 1994.

DERMIETZEL R: Gap junction wiring: a 'new' principle in cell-to-cell communication in the nervous system? Brain Res Brain Res Rev 26: 176-183, 1998.

DICKSON DW: The pathogenesis of senile plaques. J Neuropathol Exp Neurol 56: 321-339, 1997. 
ENCLANCHER F, PERRAUD F, FALTIN J, LABOURDETTE G, SENSENBRENNER M: Reactive astrogliosis after basic fibroblast growth factor (bFGF) injection in injured neonatal rat brain. Glia 3: 502-509, 1990.

GIAUME C, FROMAGET C, EL AOUMARI A, CORDIER J, GLOWINSKI J, GROS D: Gap junctions in cultured astrocytes: single-channel currents and characterization of channel-forming protein. Neuron 6: 133-143, 1991.

GIAUME C, KIRCHHOFF F, MATUTE C, REICHENBACH A, VERKHRATSKY A: Glia: the fulcrum of brain diseases. Cell Death Differ 14: 1324-1335, 2007.

HAYDON PG, CARMIGNOTO G: Astrocyte control of synaptic transmission and neurovascular coupling. Physiol Rev 86: 1009-1031, 2006.

HOZUMI I, AQUINO DA, NORTON WT: GFAP mRNA levels following stab wounds in rat brain. Brain Res 534: 291-294, 1990.

JABS R, PATERSON IA, WALZ W: Qualitative analysis of membrane currents in glial cells from normal and gliotic tissue in situ: down-regulation of $\mathrm{Na}^{+}$current and lack of P2 purinergic responses. Neuroscience 81: 847-860, 1997.

KÁLMÁN M, AJTAI BM: Lesions do not provoke GFAP-expression in the GFAP-immunonegative areas of the teleost brain. Ann Anat 182: 459-463, 2000.

KIMELBERG HK, RUTLEDGE E, GODERIE S, CHARNIGA C: Astrocytic swelling due to hypotonic or high $\mathrm{K}^{+}$ medium causes inhibition of glutamate and aspartate uptake and increases their release. J Cereb Blood Flow Metab 15: 409-416, 1995.

KIRISCHUK S, KETTENMANN H, VERKHRATSKY A: Membrane currents and cytoplasmic sodium transients generated by glutamate transport in Bergmann glial cells. Pflugers Arch 454: 245-252, 2007.

KOFUJI P, NEWMAN EA: Potassium buffering in the central nervous system. Neuroscience 129: 1045-1056, 2004.

LALO U, PANKRATOV Y, KIRCHHOFF F, NORTH RA, VERKHRATSKY A: NMDA receptors mediate neuron-toglia signaling in mouse cortical astrocytes. J Neurosci 26: 2673-2683, 2006.

LIN JH, WEIGEL H, COTRINA ML, LIU S, BUENO E, HANSEN AJ, HANSEN TW, GOLDMAN S, NEDERGAARD M: Gap-junction-mediated propagation and amplification of cell injury. Nat Neurosci 1: 494$500,1998$.

MACFARLANE SN, SONTHEIMER H: Electrophysiological changes that accompany reactive gliosis in vitro. J Neurosci 17: 7316-7329, 1997.

MACFARLANE SN, SONTHEIMER H: Spinal cord astrocytes display a switch from TTX-sensitive to TTX- resistant sodium currents after injury-induced gliosis in vitro. J Neurophysiol 79: 2222-2226, 1998.

MAGISTRETTI PJ: Neuron-glia metabolic coupling and plasticity. J Exp Biol 209: 2304-2311, 2006.

MITCHELL JD, BORASIO GD: Amyotrophic lateral sclerosis. Lancet 369: 2031-2041, 2007.

NAGELE RG, D'ANDREA MR, LEE H, VENKATARAMAN V, WANG HY: Astrocytes accumulate A beta 42 and give rise to astrocytic amyloid plaques in Alzheimer disease brains. Brain Res 971: 197-209, 2003.

NAGELE RG, WEGIEL J, VENKATARAMAN V, IMAKI H, WANG KC: Contribution of glial cells to the development of amyloid plaques in Alzheimer's disease. Neurobiol Aging 25: 663-674, 2004.

NEDERGAARD M, DIRNAGL U: Role of glial cells in cerebral ischemia. Glia 50: 281-286, 2005.

NEDERGAARD M, RANSOM B, GOLDMAN SA: New roles for astrocytes: redefining the functional architecture of the brain. Trends Neurosci 26: 523-530, 2003.

NEPRAŠOVÁ H, ANDĚROVÁ M, PETŘÍK D, VARGOVÁ L, KUBÍNOVÁ S, CHVÁTAL A, SYKOVÁ E: High extracellular $\mathrm{K}^{+}$evokes changes in voltage-dependent $\mathrm{K}^{+}$and $\mathrm{Na}^{+}$currents and volume regulation in astrocytes. Pflugers Arch 453: 839-849, 2007.

NICOTERA P, PETERSEN OH, MELINO G, VERKHRATSKY A: Janus a god with two faces: death and survival utilise same mechanisms conserved by evolution. Cell Death Differ 14: 1235-1236, 2007.

NOLTE C, MATYASH M, PIVNEVA T, SCHIPKE CG, OHLEMEYER C, HANISCH UK, KIRCHHOFF F, KETTENMANN H: GFAP promoter-controlled EGFP-expressing transgenic mice: a tool to visualize astrocytes and astrogliosis in living brain tissue. Glia 33: 72-86, 2001.

OBERHEIM NA, WANG X, GOLDMAN S, NEDERGAARD M: Astrocytic complexity distinguishes the human brain. Trends Neurosci 29: 547-553, 2006. 
ORKAND RK, NICHOLLS JG, KUFFLER SW: Effect of nerve impulses on the membrane potential of glial cells in the central nervous system of amphibia. J Neurophysiol 29: 788-806, 1966.

PASANTES MORALES H, SCHOUSBOE A: Volume regulation in astrocytes: a role for taurine as an osmoeffector. J Neurosci Res 20: 503-509, 1988.

PĚKNÝ M, NILSSON M: Astrocyte activation and reactive gliosis. Glia 50: 427-434, 2005.

PERILLAN PR, LI X, SIMARD JM: $\mathrm{K}^{+}$inward rectifier currents in reactive astrocytes from adult rat brain. Glia 27: 213-225, 1999.

PERILLAN PR, LI X, POTTS EA, CHEN M, BREDT DS, SIMARD JM: Inward rectifier K ${ }^{+}$channel Kir2.3 (IRK3) in reactive astrocytes from adult rat brain. Glia 31: 181-192, 2000.

ROITBAK T, SYKOVÁ E: Diffusion barriers evoked in the rat cortex by reactive astrogliosis. Glia 28: 40-48, 1999.

ROSSI DJ, BRADY JD, MOHR C: Astrocyte metabolism and signaling during brain ischemia. Nat Neurosci 10: 13771386, 2007.

SCEMES E, GIAUME C: Astrocyte calcium waves: what they are and what they do. Glia 54: 716-725, 2006.

SCHRODER W, HAGER G, KOUPRIJANOVA E, WEBER M, SCHMITT AB, SEIFERT G, STEINHAUSER C: Lesion-induced changes of electrophysiological properties in astrocytes of the rat dentate gyrus. Glia 28: 166174, 1999.

SELKOE DJ: Alzheimer's disease: genes, proteins, and therapy. Physiol Rev 81: 741-766, 2001.

SOMJEN GG: Extracellular potassium in the mammalian central nervous system. Annu Rev Physiol 41: 159-177, 1979.

SOMJEN GG: Mechanisms of spreading depression and hypoxic spreading depression-like depolarization. Physiol Rev 81: 1065-1096, 2001.

SYKOVÁ E: Extracellular K ${ }^{+}$accumulation in the central nervous system. Prog Biophys Mol Biol 42: 135-189, 1983.

SYKOVÁ E: Extracellular space volume and geometry of the rat brain after ischemia and central injury. Adv Neurol 73: 121-135, 1997.

SYKOVÁ E: Glia and volume transmission during physiological and pathological states. $J$ Neural Transm 112: 137$147,2005$.

SYKOVÁ E, CHVÁTAL A: Glial cells and volume transmission in the CNS. Neurochem Int 36: 397-409, 2000.

SYKOVÁ E, SVOBODA J, ŠIMONOVÁ Z, JENDELOVÁ P: Role of astrocytes in ionic and volume homeostasis in spinal cord during development and injury. Prog Brain Res 94: 47-56, 1992.

SYKOVÁ E, VARGOVÁ L, PROKOPOVÁ S, ŠIMONOVÁ Z: Glial swelling and astrogliosis produce diffusion barriers in the rat spinal cord. Glia 25: 56-70, 1999.

TOWER DB: A century of neuronal and neuroglial interactions, and their pathological implications: an overview. Prog Brain Res 94: 3-17, 1992.

ULLIAN EM, CHRISTOPHERSON KS, BARRES BA: Role for glia in synaptogenesis. Glia 47: 209-216, 2004.

VARGOVÁ L, CHVÁTAL A, ANDĚROVÁ M, KUBÍNOVÁ S, ŽIAK D, SYKOVÁ E: Effect of osmotic stress on potassium accumulation around glial cells and extracellular space volume in rat spinal cord slices. $J$ Neurosci Res 65: 129-138, 2001.

VERKHRATSKY A: Calcium ions and integration in neural circuits. Acta Physiol (Oxf) 187: 357-369, $2006 \mathrm{a}$.

VERKHRATSKY A: Patching the glia reveals the functional organisation of the brain. Pflugers Arch 453: 411-420, 2006b.

VERKHRATSKY A, BUTT A: Glial Neurobiology. A textbook. John Wiley \& Sons, Chichester, 2007.

VERKHRATSKY A, KIRCHHOFF F: Glutamate-mediated neuronal-glial transmission. $J$ Anat 210: 651-660, 2007a.

VERKHRATSKY A, KIRCHHOFF F: NMDA Receptors in glia. Neuroscientist 13: 28-37, $2007 \mathrm{~b}$.

VERKHRATSKY A, STEINHAUSER C: Ion channels in glial cells. Brain Res Brain Res Rev 32: 380-412, 2000.

VERKHRATSKY A, TOESCU EC: Neuronal-glial networks as substrate for CNS integration. J Cell Mol Med 10: 826836, 2006.

VERKHRATSKY A, ORKAND RK, KETTENMANN H: Glial calcium: homeostasis and signaling function. Physiol Rev 78: 99-141, 1998.

VIJAYAN VK, LEE YL, ENG LF: Increase in glial fibrillary acidic protein following neural trauma. Mol Chem Neuropathol 13: 107-118, 1990. 
VOLTERRA A, MELDOLESI J: Astrocytes, from brain glue to communication elements: the revolution continues. Nat Rev Neurosci 6: 626-640, 2005.

VOŘÍŠEK I, SYKOVÁ E: Ischemia-induced changes in the extracellular space diffusion parameters, $\mathrm{K}^{+}$, and $\mathrm{pH}$ in the developing rat cortex and corpus callosum. J Cereb Blood Flow Metab 17: 191-203, 1997.

WALZ W: Role of astrocytes in the spreading depression signal between ischemic core and penumbra. Neurosci Biobehav Rev 21: 135-142, 1997.

WESTBROOK GL: Glutamate receptors and excitotoxicity. Res Publ Assoc Res Nerv Ment Dis 71: 35-50, 1993.

WISNIEWSKI HM, WEGIEL J: Spatial relationships between astrocytes and classical plaque components. Neurobiol Aging 12: 593-600, 1991.

YAGITA Y, KITAGAWA K, SASAKI T, MIYATA T, OKANO H, HORI M, MATSUMOTO M: Differential expression of Musashil and nestin in the adult rat hippocampus after ischemia. $J$ Neurosci Res 69: 750-756, 2002.

YU SP: $\mathrm{Na}^{+}, \mathrm{K}^{+}$-ATPase: the new face of an old player in pathogenesis and apoptotic/hybrid cell death. Biochem Pharmacol 66: 1601-1609, 2003.

ZONTA M, ANGULO MC, GOBBO S, ROSENGARTEN B, HOSSMANN KA, POZZAN T, CARMIGNOTO G: Neuron-to-astrocyte signaling is central to the dynamic control of brain microcirculation. Nat Neurosci 6: 4350, 2003. 